\title{
Ontogenetic Development of Hedysarum Alpinum L. in Prebaikalia
}

By Elena G. Khudonogova, Alena A. Mikhlyaeva \& Svetlana V. Polovinkina Irkutsk State Agrarian University

Abstract- Hedysarum alpinum $L$. is an important medicinal plant, which also has ornamental value and is used as a non-conventional feed resource. The medicinal value of this plant species is attributable to the content of the glycoside mangiferin in the aerial parts of a plant, which demonstrates immunostimulating properties. Harvesting of $H$. alpinum as a herbal raw material leads to a fast depletion of natural coenopopulation areas. When cultivated in Prebaikalia, the plant passes through all ontogenetic stages, entering the reproductive phase at year 2-3 of growth. The mid-reproductive stage, which is the most productive for feeding purposes, lasts 6 to 10 years. For introduced species, the life span of a plant growing in the same place ranges between 12 and 20 years. $\mathrm{H}$. alpinum is a promising medicinal and fodder plant, which tolerates dry summer periods, is winter-hardy, and has high shoot biomass production.

Keywords: hedysarum alpinum, fodder plant, medicinal, ornamental, ontogenesis, introduction.

GJSFR-C Classification: FOR Code: 060499

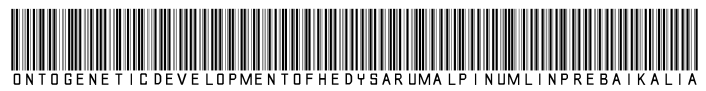

Strictly as per the compliance and regulations of:

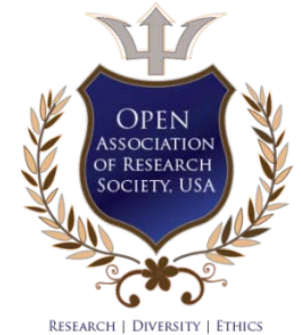

(C) 2020. Elena G. Khudonogova, Alena A. Mikhlyaeva \& Svetlana V. Polovinkina. This is a research/review paper, distributed under the terms of the Creative Commons Attribution-Noncommercial 3.0 Unported License http://creativecommons.org/ licenses/by-nc/3.0/), permitting all non commercial use, distribution, and reproduction in any medium, provided the original work is properly cited. 


\title{
Ontogenetic Development of Hedysarum Alpinum L. in Prebaikalia
}

\author{
Elena G. Khudonogova ${ }^{\alpha}$, Alena A. Mikhlyaeva ${ }^{\circ} \&$ Svetlana V. Polovinkina ${ }^{\rho}$
}

\begin{abstract}
Hedysarum alpinum $L$. is an important medicinal plant, which also has ornamental value and is used as a nonconventional feed resource. The medicinal value of this plant species is attributable to the content of the glycoside mangiferin in the aerial parts of a plant, which demonstrates immunostimulating properties. Harvesting of $H$. alpinum as a herbal raw material leads to a fast depletion of natural coenopopulation areas. When cultivated in Prebaikalia, the plant passes through all ontogenetic stages, entering the reproductive phase at year 2-3 of growth. The midreproductive stage, which is the most productive for feeding purposes, lasts 6 to 10 years. For introduced species, the life span of a plant growing in the same place ranges between 12 and 20 years. $H$. alpinum is a promising medicinal and fodder plant, which tolerates dry summer periods, is winter-hardy, and has high shoot biomass production.
\end{abstract}

Keywords: hedysarum alpinum, fodder plant, medicinal, ornamental, ontogenesis, introduction.

\section{InTRODUCTION}

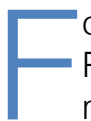
odder production in an especially relevant issue in Prebaikalia with its developed livestock farming. In recent years, along with the bringing of wild plants into cultivation and development of new varieties of fodder crops, special attention has been paid to nonconventional plants, in particular Hedysarum alpinum $L$. (common name: alpine sweetvetch), which is a valuable fodder, medicinal and ornamental plant. In the study territory $\mathrm{H}$. alpinum is has not been used as a fodder or ornamental plant, both due to conventional reasons and insufficient knowledge of this species.

H. alpinum is a perennial herbaceous plant of the family Fabaceae, growing up to $40-120 \mathrm{~cm}$ in height. Stem: upright, bare. Rhizome: thick, long, branched. Leaves: unpaired, 5-9 (10) pairs, oblong-ovate or elongated-elliptical, appressed-pilose on the top. Inflorescence: long thick multi-flowered raceme with 2030 flowers. Flowers: up to $15 \mathrm{~mm}$ long, papilionaceous, on short pedicels with linear bracts, corollas pink, lilac or purple, rarely white, turn purple when dried. Bracts are usually shorter than pedicels. Calyx: about $4 \mathrm{~mm}$ long, bell-shaped, irregular, wide-triangular, the smallest calyces are 2-4 times shorter than the calyx tube. Corollas: 10-14 mm long, the keel is slightly longer than wings and the banner, or is nearly the size of the latter.

Author $\alpha \quad \rho$ : Department of Botany, Horticulture and Landscape Architecture, Irkutsk State Agrarian University named after A.A. Yezhevskiy, Irkutsk Oblast, Irkutsk Rayon, 664038 Molodezhnyy, Russia. e-mail: doky2015@yandex.ru
Fruit: bean (8-10 mm long), bean segments: 1-4 (2-5), round-oval, with narrow margins, easily breaking off. Each segment contains one seed enclosed in a hard shell. Bloom period: June-July, ripening: from August to early September [1].

Herbal raw materials are harvested for medicinal use in the blooming period (herb) and during withering of the aerial parts of plants, usually in September (roots). H. alpinum herb contains mangiferin, which demon states antiviral activity against herpes simplex, chickenpox, and cytomegaloviruses. Mangiferin is also known as an immunostimulant due to its stimulating action on cellular and humoral immunity and stimulation of the production of gamma-interferon in blood cells; it is used as an active ingredient in the newly developed "Alpizarin" drug. The aerial part contains quercetin, quercetrin, avicularin. Leaves contain flavonoids: hyperoside, mangiferin, isomangiferin, polystachoside and hedizaride, traces of alkaloids, ascorbic acid (up to $137.5 \mathrm{mg} \%$ ); herb contains triterpene saponins. The underground parts of a plant contain $30-40 \%$ of polysaccharides, which hydrolyze down to galactose, xylose, galacturonic acid, and low amounts of rhamnose. The sweetvetch root decoction is used in traditional medicine as an expectorant for treatment of coughing, bronchitis and pulmonary tuberculosis, as well as a sedative for treatment of nervous disorders, insomnia, epilepsy, heartache, and atherosclerosis [2,3,4,5,6].

In the territory of the Russian Federation $\mathrm{H}$. alpinum its habitat area spreads from the south of the Kola Peninsula to the Urals and Siberia. It grows in the forest and forest-steppe zone along river and stream valleys. It grows riotously in shrub-and-grass meadows on well-drained, elevated sections of the central parts of floodplains [1].

It grows in the southern regions of Irkutsk Oblast, in the Sayan Mountains, in the Lake Baikal area, in Buryatia, in the Yablonovy Mountains and in Dauria, where is occupies moist forest meadows, shrubs, and river valleys.

No large beds of $H$. alpinum were found in Prebaikalia. Harvesting of $H$. alpinum as a herbal raw material leads to a fast depletion of natural coenopopulation areas.

To preserve this species, introduction studies must be carried out based on the investigation of 
ontogenesis of a species under conditions of the study area.

The aim of the present study was to investigate the ontogenetic development of $H$. alpinum introduced in the forest-steppe zone of the southwestern Prebaikalia. Research objectives: based on morphological characteristics, identify ontogenetic states of the species, trace the progress of $H$. alpinum ontogenesis in the Western Cisbaikalia.

\section{il. Materials and Methods}

Study object: $H$. alpinum. Investigation of the ontogenetic state of the species was carried out in the training and experimental field of Irkutsk State Agrarian University. Scarified $H$. alpinum seeds were planted in

May and September.

Planting method: wide-row planting. The soil in the Experimental field: grey wood soil.

The age-state structure of coenopopulations of useful plants was determined using a standard method for studying the age-state structure of populations making up the plant association, and in compliance with principles and methods for studying the age structure of coenopopulations developed by Yu.A. Zlobin [7] and Ye.L. Nukhimovskiy [8]. Description of ontogenesis $H$. alpinum growing in Prebaikalia also took into account the data on species biology obtained in the studies by L.I. Fomina carried out in Chita Oblast [9], by N.S. Zinner in the forest-steppe zone of Siberia [10], by N. Portnyagina et al. in the Komi Republic $[11,12,13]$, and by N.A. Karnaukhova, D.V. Sandanov, I.Yu.Selyutina in Buryatia [14].

\section{Iil. Results and Discussion}

Cisbaikalia (or Pribaikalia) is a vast region in the south of Eastern Siberia located in the center of Asia with an area of over 800 thousand sq.km. Cisbaikalia is considered to include the entire area adjacent to Lake Baikal, while the western territories, in a similar way to Transbaikalia (meaning "beyond" (trans-) Lake Baikal), is called Prebaikalia (i.e. "before" Lake Baikal). In the system of physical and geographical zoning of Siberia, most of the Cisbaikalia territory is occupied by two physical and geographical areas: Central Siberia and the mountains of Southern Siberia. According to the landscape zoning of the south of Eastern Siberia, the Cisbaikalia territories occupied by taiga belong to three physical and geographical regions of North Asia: Central Siberian, South Siberian, and Baikal-Dzhugdzhur regions.

The climate of Prebaikalia is determined by the geographical latitude and the position of Lake Baikal almost in the center of Asia, which result in a harsh continental climate. The average January temperature in Cisbaikalia can go down to $-20^{\circ} \mathrm{C}$. The average air temperature in July reaches $+15^{\circ} \mathrm{C}$ in the mountainous regions along the shores of Lake Baikal, and $+18{ }^{\circ} \mathrm{C}$ in the central regions of Cisbaikalia. Climate of Prebaikalia is determined by the geographical latitude and the position of Lake Baikal almost in the center of Asia, which result in a harsh continental climate. The average January temperature in Cisbaikalia can go down to $20{ }^{\circ} \mathrm{C}$. The average air temperature in July reaches +15 ${ }^{\circ} \mathrm{C}$ in the mountainous regions along the shores of Lake Baikal, and $+18^{\circ} \mathrm{C}$ in the central regions of Cisbaikalia. The sum of air temperatures above $10^{\circ} \mathrm{C}$ is $1550-1670{ }^{\circ} \mathrm{C}$, and the frost-free period lasts about 100 days. Maximum air fluctuations are observed in early spring and late autumn. Annual precipitation ranges 380-480 mm [15].

In the entire Prebaikalia, the most prevalent type of soils is grey wood soils [16], while in island steppes chestnut soils, and less often chernozem and meadow chernozem can be found. There are also saline-alkali soils, and black alkali soils.

Our study results show that $H$. alpinum introduced in the region goes through the following ontogenetic stages (Fig. 1):

1. Seedling stage: a 1-1.5 high shoot is formed, with 13 simple broadly ovate or rarely round leaves and a 1-3 cm long taproot, with clearly visible roundshaped, yellowish cotyledons [17].

2. Juvenile stage: monopodial shoot growth continues, cotyledons whither. At this stage, two subgroups can be distinguished: subgroup 1 of juvenile plants (shoot height increases to $1.6-2 \mathrm{~cm}$, the number of simple leaves increases to $3-6$, the primary root begins to branch off to secondary roots), and subgroup 2 of juvenile plants (shoot height of 1.7$2.3 \mathrm{~cm}$, with 1-3 ternate leaves appearing on a shoot in addition to simple leaves). In the basal portion of a shoot, 1-3 cataphyll leaves are formed, the $3-5 \mathrm{~cm}$-long primary root begins to branch off to secondary roots, the root is thin, with a diameter of 1.0 to $1.6 \mathrm{~mm}$. In the region of cotyledonary nodes, two primary buds are formed $(1 \mathrm{~mm}$ wide, $2-2.5 \mathrm{~mm}$ high), in the axils of which an additional small third bud is formed, and in turn, in the axils of the third bud is the fourth bud. At this, all buds are formed in a ladder-like manner: with the base of each bud slightly above the other. All buds are different in terms of the stage of formation, they are mostly poorly formed, but in the next year of life they give fast-growing shoots with sympodial branching.

The juvenile stage duration varies from 1-3 months to a year. Some plants enter the immature stage already in the first year of growth, while others enter the immature stage only the next year.

3. Immature stage. Individuals that entered the immature stage during the first vegetative phase remain single-shooted, the shoot $(2.5-3 \mathrm{~cm}$ high) continues to grow monopodially, sometimes with 
weak branching, in addition to 3-6 simple leaves, 13 small ternate leaves $(0.1-0.5 \mathrm{~cm}$ long) are formed on a shoot, the primary root thickens and begins to deepen into soil.

In plants that entered the immature stage in the following year, the major shoot withers away, and a new major shoot grows from innovation buds located in the cotyledonary node regions. Shoots of immature plants branch in a sympodial manner. The first imparipinnate leaves, in the number of 2-5 pairs or more, appear on shoots. The primary root (5-7 $\mathrm{cm}$ long) deepens $10-20 \mathrm{~cm}$ into soil and thickens (root diameter $1.7-2.1 \mathrm{~mm}$ ), root buds can be seen, giving growth to multiple secondary and tertiary roots.

4. Virginile stage. $H$. alpinum enters the virginile stage during the second year of growth. The innovation starts in the buds located in axils of cataphyll leaves. Multiple imparipinnate leaves (2 - 6 pairs) unfold along the shoot axis. Plants begin to form caudex from the remaining last year's shoots (root length - 15-20 cm, root diameter - 2-2.5 cm). New shoots emerge from latent buds. The root has auxiliary buds, which can also give rise to new shoots. The duration of the virgin state is about 1 year.

5. Plants usually enter the reproductive stage at the third year of growth. In the case of underwinter sowing, single plants may bloom in the second year.

Plants at the early-reproductive stage form 1-2 (2-5) reproductive shoots with 4-7 pairs of imparipinnate leaves. Caudex becomes two- or many-headed, taproot develops multiple thickened lateral roots. Cultivated plants remain in this state for about 1-2 years.

Plants at the mid-reproductive stage form multiple reproductive shoots (15-20 or more) bearing 7-9 or rarely up to 10-14 pairs of imparipinnate leaves. At the tops of shoots an inflorescence is formed as a dense raceme of flowers. During this period, shoots rapidly grow and thicken (shoot height 1.0-1.25 $\mathrm{m}$ or more), the partial caudex and the primary root become significantly thicker (primary root diameter: $2.8 \mathrm{~cm}$ or more). This stage lasts 6-10 years.

Plants enter the late-reproductive stage at the age of 9-14 years, and at this time the number of reproductive shoots of a plant decreases down to 25 , their seed productivity is significantly reduced. The caudex particulation begins in the central part. This stage lasts about 2-3 years or more.

6. Subsenile plants bear vegetative shoots growing from latent buds located in the caudex, at the same time the number of leaf pairs decreases (to 6-8). Plants stop flowering. The subsenile stage is characterized by incomplete caudex particulation. This stage lasts about 2 years.

7. Senile stage: at this stage individuals are in a depressed state, the number of vegetative of shoots is $1-2$, necrotic caudex particulation is clearly visible, with the caudex completely destroyed in the center. Plant individuals remain at this stage for 1-2 years.

In Prebaikalia $H$. alpinum goes through all age periods of development: from immature and virginile to reproductive and senile.

The lifespan of $\mathrm{H}$. alpinum introduced in the southwest Prebaikalia is from 12 to 20 years, at this, seedlings germinate in 10-15 days, the juvenile stage lasts from 1-3 months to 1 year. Some individuals enter the immature stage already at their first year of life, while others enter the immature stage only next year. The virginile stage lasts for about one year. Plants usually enter the reproductive stage in the third year of their growth; and winter-sown individuals may flower during the second year, but only very few of them. The duration of the reproductive stage is from 9 to 14 years. The subsenile stage is characterized by an incomplete caudex particulation and lasts for 2 years. A plant quickly enters a senile stage, which is characterized by a complete caudex particulation and the subsequent death after overwintering.

Alpine sweetvetch goes through a full development cycle: it grows, blooms, bears fruit, forms viable seeds (3.02 $\pm 0.1 \mathrm{~mm}$ long and $1.97 \pm 0.09 \mathrm{~mm}$ wide). The weight of 1000 pieces of seeds ranges from 4.24 to $6.17 \mathrm{~g}$. Seed germination rate is $40-68 \%$.

Mechanical scarification, light, and removal of seed pericarp improve germination rates and increase the germination energy to $58-88 \%$.

In the first year after sowing, the plant develops slowly, forming one brittle shoot, so in this period it is nearly unable to compete with weeds. Like many other legumes, the sweetvetch forms a symbiotic relationship with nitrogen-fixing bacteria. Many researchers consider the slow growth of $H$. alpinum in the first year of life to be due to an insufficient number of nitrogen-fixing bacteria; therefore, when seeds are planted in the soil where this species did not grow before, it is recommended to sprinkle the seeds with soil taken from under adult individuals of the species. In the next years, $H$. alpinum perfectly adapts to the climatic conditions of Prebaikalia, being a frost- and drought-tolerant species, competitively resistant to weeds. Plants have a relatively long life span and can grow in the same place for 10 years or longer.

The 7-year study of biomorphology (Table 1), demonstrated that the productivity was the highest in middle-age reproductive stage plants, which had the highest shoot growth gain (up to $16.5 \pm 1.2$ ), shoot height (up to $130.2 \pm 4.0 \mathrm{~m}$ ), number of leaves per shoot (up to 16.0), plant mass per plant (up to $120.2 \pm$ 
$1.9 \mathrm{~g})$. The productivity of plants at the mid-reproductive stage was affected by the plant age, geographical location of the region, climatic conditions of the study area, environmental $[18,19]$ and other factors. Thus, for example, several authors observed the highest biomass in 4-year-old reproductive plants in the Chita region (up to $13.7 \mathrm{~g}$ ) [9], and in 8-year-old plants cultivated in the middle-taiga subzone of the Komi Republic (from 91 to $114 \mathrm{~g})[11,12,13]$ and in Tomsk Oblast (up to $174.2 \mathrm{~g}$ ) [20]. n Prebaikalia, the most productive are 7-year-old plants (up to $120 \mathrm{~g}$ ).

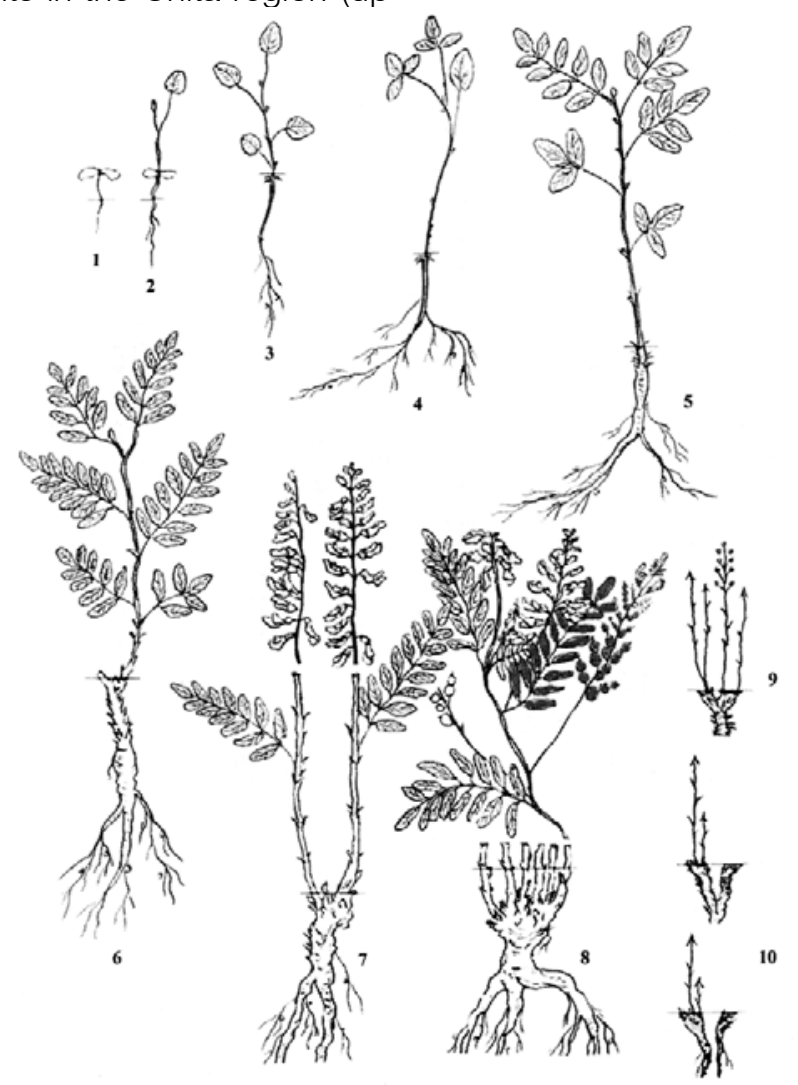

Fig. 1: Ontogenetic development of Hedysarum alpinum L. growing in Prebaikalia: 1. Seedling; 2. Juvenile plant of subgroup 1; 3. Juvenile plant of subgroup 2; 4. Immature plant, 5. Virginile plant; 6. Early-reproductive stage plant; 7. Middle-reproductive stage plant; 8. Late- reproductive stage plant; 9. Subsenile plant; 10. Senile plant

Table 1: Biomorphology of Hedysarum alpinum L. growing in the conditions of Prebaikalia

\begin{tabular}{|c|c|c|c|c|c|}
\hline \multirow[b]{2}{*}{ Year of life } & \multicolumn{3}{|c|}{ Reproductive shoots } & \multirow[b]{2}{*}{$\begin{array}{l}\text { Weight of seeds } \\
\text { per one plant (g) }\end{array}$} & \multirow[b]{2}{*}{$\begin{array}{l}\text { Phytomass per } \\
\text { plant (g) (air-dry) }\end{array}$} \\
\hline & $\begin{array}{l}\text { Number of } \\
\text { shoots }\end{array}$ & $\begin{array}{l}\text { Shoot height } \\
\text { (cm) }\end{array}$ & $\begin{array}{c}\text { Number of leaves } \\
\text { per shoot }\end{array}$ & & \\
\hline 3 & $3.1 \pm 0 ., 5$ & $69,4 \pm 4,8$ & $12.0 \pm 1.1$ & - & $30.2 \pm 2.7$ \\
\hline 4 & $4.5 \pm 0.8$ & $88.6 \pm 6,5$ & $13.5 \pm 0.7$ & $9.0 \pm 0.6$ & $42.5 \pm 1.9$ \\
\hline 5 & $8.3 \pm 0 ., 3$ & $112.5 \pm 5.5$ & $13.6 \pm 1.0$ & $17.2 \pm 1.0$ & $86,5 \pm 3.6$ \\
\hline 6 & $13.7 \pm 0.9$ & $120.0 \pm 3.6$ & $16.0 \pm 1.5$ & $25.8 \pm 2.9$ & $117.0 \pm 1.5$ \\
\hline 7 & $16.5 \pm 1.2$ & $130.2 \pm 4.0$ & $15.3 \pm 1.9$ & $38.5 \pm 3.0$ & $120.2 \pm 1.9$ \\
\hline
\end{tabular}

\section{Conclusion}

When cultivated in Prebaikalia, the plant passes through all ontogenetic stages, entering the reproductive phase at year 2-3 of growth. The duration of the most productive for feeding purposes midreproductive stage is 6-10 years. For introduced species, the life span of a plant growing in the same place ranges between 12 and 20 years. $H$. alpinum is a promising medicinal and fodder plant, which tolerates dry summer periods, is winter-hardy, and has high shoot biomass production (up to $120.2 \mathrm{~g}$ per plant on year 7 of growth).

\section{References Références Referencias}

1. Malankina Ye.L. (2017) Kopeyechnik alpiyskiy: lekarstvennye svoystva i vyrashchivanie [Alpine sweetvetch: medicinal properties and cultivation] 
[Electronic source]. Gardening, Floriculture and Landscaping Information Portal. Accessed October 06, 2017 at: https://www.greeninfo.ru/wild_growing/ hedisarum_alpinum.html/Article/_/alD/5867 (in Russian).

2. Golovkin B.N., Rudenskaya R.N., Trofimov I.A., Shreter A.I. (2001) Biologicheski aktivnye veshchestva rastitelnogo proiskhozhdeniya [Biologically active substances of plant origin]. Moscow, Science. 764 (in Russian).

3. Zinner N.S., Vysochina G.I., Kukushkina T.A., Sviridova T.P. (2010) Biologicheski aktivnye veshchestva Hedisarum alpinum L. i H. theinum Krasnob. (Fabaceae), introduitsiruyemykh $v$ Tomskuyu oblast [Biologically active substances of Hedisarum alpinum L. and $H$. theinum Krasnob. (Fabaceae) being introduced in the Tomsk region]. Vestnik Tomskogo Gosudarstvennogo Universiteta. Biologiya [Tomsk State University Journal of Biology]. 4 (12): 116-121 (in Russian).

4. Kuznetsov E.I., Dytskova E.V., Zhuchenko A.A. (2006) Ekologicheski bezopasnaya tekhnologiya vozdelyvaniya kopeyechnika alpiyskogo [Environmentally-friendly technology for cultivation of Alpine sweetvetch]. Izvestiya of Timiryazev Agricultural Academy (TAA) (278), 108-113 (in Russian).

5. Punegov V., Fomina M., Chucha K. (2015) Soderzhanie mangiferina $v$ syryevoj fitomasse $i$ organakh rasteniya Hedysarum alpinum L. v kulture $v$ sredney podzone taygi Respubliki Komi [The content of mangiferin in the raw biomass and organs of Hedysarum alpinum L. cultivated in the middle-taiga subzone of the Republic of Komi]. Vestnik of the Institute of Biology of the Komi Science Center UB RAS (6): 13-16 (in Russian).

6. Telyatyev V (1991) Tselebnye klady [Healing treasures]. Irkutsk 400p. (in Russian).

7. Zlobin Yu.A. (1989) Printsipy i metody izucheniya tsenoticheskikh populyaciy rasteniy. [Principles and methods for investigations of coenotic plant populations]. Kazan, Kazan Federal University Publishing house 94-115 (in Russian).

8. Nukhimovskiy Ye.L. (1997) Osnovy biomorfologii semennykh rasteniy. [Basics of biomorphology of seed plants]. Moscow, Nedra Publishers (1), 355356 (in Russian).

9. Fomina L.I. (1990) Osobennosti razvitiya Hedysarum alpinum L. i Lespedeza hedysaroides (Pall.) Kitag. (sem. Fabaceae) v Chitinskoy oblasti [Development of Hedysarum alpinum L. and Lespedeza hedysaroides (Pall.) Kitag. (fam. Fabaceae) in the Chita region]. Extended abstract of dissertation thesis for fulfillment of the degree of Candidate of Sciences (PhD). Leningrad (in Russian).

10. Zinner N.S. (2011) Biologicheskiye osobennosti Hedysarum alpinum L. i Hedysarum theinum
Krasnob. pri introduktsii $v$ usloviyakh lesnoy zony Zapadnoy Sibiri [Biological aspects of Hedysarum alpinum L. and Hedysarum theinum Krasnob. during introduction in the forest zone of Western Siberia]. Extended abstract of dissertation thesis for fulfillment of the degree of Candidate of Sciences (PhD). Tomsk (in Russian).

11. Portnyagina N.V., Fomina M.G., Punegov V.V., Zaynullina K.S., Echishvili E.E. (2014) Itogi introduktssii Hedysarum alpinum L. v usloviyakh srednetayozhnoy podzony $v$ Respublike Komi [Outcomes of introduction of Hedysarum alpinum L. in the midle-taiga subzone in the Komi Republic]. Izvestiya of the Samara scientific center of the Russian Academy of Sciences, vol. 16. 1(13): 796799 (in Russian).

12. Portnyagina N., Fomina M., Echishvili E. (2015) Kopeyechnik alpiyskiy (Hedysarum alpinum L.) V kulture srednej podzony taygi Respubliki Komi. [Alpine sweetvetch (Hedysarum alpinum L.) cultivated in the middle-taiga subzone of the Komi Republic.] Vestnik of the Institute of Biology of the Komi Science Center UB RAS (6): 6-10 (in Russian).

13. Portnyagina N.V., Skrotskaya O.V., Zaynullina K.S., Echishvili E.E., Mikhovich Zh.E., Fomina M.G., Punegov V.V., Miftakhova S.A. (2016) Opyt kultivirovaniya lekarstvennykh rasteniy na Severe (Respublika Komi) [Cultivation of medicinal plants in the North (Komi Republic)]. Izvestiya of the Samara scientific center of the Russian Academy of Sciences, vol. 18(2): 172-176 (in Russian).

14. Karnaukhova N.A., Sandanov D.V., Selyutina I.Yu. (2007) Sravnitelnaya otsenka ontogeneticheskoy struktury i morfologicheskikh priznakov $v$ tsenopopulyatsiyakh Hedisarum alpinum L. v Buryatii [Comparative evaluation of ontogenetic structure and morphology of Hedisarum alpinum $L$. coenopopulations in Buryatia]. Вестник Бурятского государственного университета (3), 167-169 (in Russian).

15. Berkin N.S., Filippov S.A., Boyarkin A.M. et al. (1993) Irkutskaya oblast (prirodnyye usloviya administrativnykh rayonov) [lrkutsk Oblast (natural conditions of administrative regions)]. Irkutsk: Publishing house of Irkutsk State University300 (in Russian).

16. Ryabinina O.V. (2012) Otsenka svoystv seroy lesnoy pochvy pod posevami mnogoletnikh [Evaluation of grey wood soil properties under perennial plants] // Vestnik of the Irkutsk State Agricultural Academy (Vestnik IrGSHA). 52: 21-28 (in Russian).

17. Filatova N.V., Lukina I.A. (2013) Vliyaniye usloviy vneshney sredy na ranniye etapy ontogeneza Hedysarum alpinum Ledeb $i$ Hedysarum flavescens Regel et Schmalh v usloviyakh Prebaikalya [Influence of environmental conditions on early ontogenesis of Hedysarum alpinum Ledeb and Hedysarum 
flavescens Regel et Schmalh growing in Prebaikalia]. Proceedings of research and practice workshop dedicated to the "Day of PhD-student". Irkutsk121125 (in Russian).

18. Mikhlyaeva A.A., Khudonogova E.G. (2018) Ekologicheskiye osobennosti Hedysarum alpinum L. $\checkmark$ usloviyakh Predbajkalya [Ecology of Hedysarum alpinum L. in Prebaikalia]. Vestnik of the Irkutsk State Agricultural Academy (Vestnik IrGSHA). (88): 36-44 (in Russian).

19. Khudonogova E., Tretyakova S., Mikhlyaeva A., Tungrikova V., Rachenko M. Ecological features of useful plants in natural populations of the Western Baikal region: XIX International Multidisciplinary Scientific GeoConference SGEM 2019 (Ecology and Environmental Protection), June 30-July 6, (2019) Bulgaria. 301-306.

20. Sviridova T.P., Zinner N.S. (2008) Perspektivy vyrashchivaniya Hedusarum alpinum L. i Hedysarum theinum Krasnob. $v$ usloviyakh Tomskoy oblasti [Prospects for growing Hedysarum alpinum L. and Hedysarum theinum Krasnob. in Tomsk Oblast]. Vestnik Tomskogo Gosudarstvennogo Universiteta. Biologiya [Tomsk State University Journal of Biology] (2): 11-12 (in Russian). 